\title{
Modeling and Simulation of Solar PV Energy Conversion Systems
}

\author{
Bharathy Priya D, A.Sumathi
}

\begin{abstract}
This paper explores the role of Power Electronic technology has been utilized in various types of applications where electrical power produced and distributed especially in Solar Photovoltaic Panel Systems. In this paper, discussed about designing and modeling of solar photovoltaic system parameters such as saturation current, photo current, reverse saturation current, shunt resistor current, voltage versus current characteristics and voltage vs power characteristics of solar photovoltaic cell that is simulated using MATLAB Simulink.
\end{abstract}

Keywords: PV cell, Modeling, parameters of PV cell, MATLAB Simulink

\section{INTRODUCTION}

Over the last decade, numerous renewable energy system technologies were developed based on reliability, flexibility, stability, accessibility, economical. Renewable energy technologies are becoming more affordable new with decline in prices as demand and production increases. In addition to sunlight and wind, India has numerous sustainable power resources such as biomass, tidal power, geo-thermal energy etc. Most recent trends on power electronics sustainable power sources are photovoltaic and wind power system. Solar as well as wind power are likely to be a part of the solution to the climatic change problem. This varies due to meteorological/climatological processes operating at a wide range of seasonal changes, synopticscale weather patterns, diurnal cycle, small-scale turbulence and even longer term processes.

\section{A Solar Energy Conversion System}

Solar energy is the transformation of daylight into power or heat by employing direct or indirect way. Solar energy conversion is based on any one of the three methods-direct, Indirect and hybrid. Direct Method is done by using photovoltaics. Indirect method is done by using Solar Thermal Collectors, Solar architecture (passive solar building design).Hybrid method is done by using PVT systems, CPV/CSP system. Photovoltaic cells captures the daylight and generates DC power. A Photovoltaic inverter gets the DC power and converting into AC electricity that can be utilized for power buildings. The alternating energy is transferred from the inverter to the electrical panels of the building. The net energy tracks the utility produced with the utility electric meter [1]. Solar power system consists of photovoltaic array cells that generate power from sunlight.

Figure 1 shows the Photovoltaic cell as the main source of energy, charge controller, electric storage devices (battery), control circuit such as MPPT and Protection circuit. Photovoltaic modules are connected to the grid with one inverter per string in series and/or parallel in the form of a single string [5]. These PV strings have a dc to dc step-up regulators and Inverter offering the possibility of control circuit such as MPPT to maximizing PV system's power output.

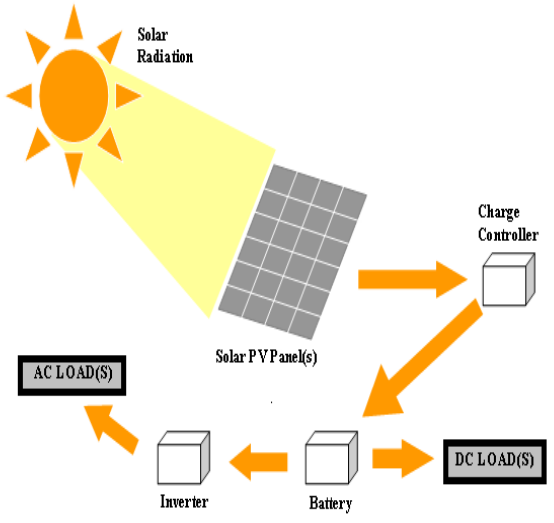

Figure 1. Solar Energy Conversion system Block diagram

\section{B. Energy Storage Devices for Solar Photovoltaic system}

It needs the storage capacity of battery that help to satisfy the demand for energy while periods of less solar irradiation also during night period. Some of the most popular solar battery types are available for example nickel-cadmium battery, zinc bromide battery, lead acid battery, , nickelhydrogen battery ,zinc chloride battery, lithium battery, sodium sulphur battery, redox and vanadium battery. Typically, lead acid batteries are utilized to provide energy storage for several hours to a few days [8]. Advantages of lead acid batteries are low cost, availability, portable and hence used in remote area power supplies .Lead acid battery depends on deep or shallow cycling gelled battery, batteries with capacitive type or liquid type electrolyte, sealed battery and non-sealed battery. Sealed batteries are easy to maintain compared with other types of batteries. Sealed batteries are regulated by the valve to allow expansion of excess hydrogen gas.

The following considerations for selecting batteries for Photo voltaic applications:
Revised Manuscript Received on 14 August, 2019.

Bharathy Priya .D, Research Scholar, Adhiyamaan College of Engineering, Hosur, Tamilnadu, India.(Email: dbharathypriya@ gmail.com)

A.Sumathi, PG Professor and Head of ECE Department, Adhiyamaan College of Engineering, Hosur, Tamilnadu, India. (Email: sumathi_2005@rediffmail.com)

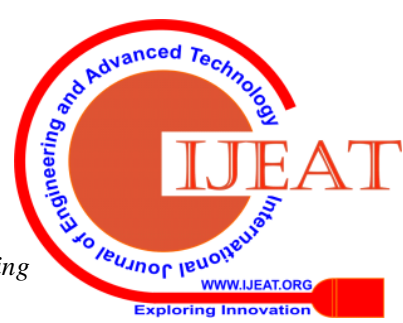


- Low cost.

- Less maintenance.

- $\quad$ Long hours of life.

- $\quad$ High efficiency in energy storage.

- $\quad$ Reduced self-discharge

- Intermittent and fluctuating charge as well as discharge

- Deep duration charge and discharge.

- Low charging/discharging current

- Deep discharge.

- PV applications is based on stand-alone solar system

- $\quad$ Photovoltaic including storage capacity for battery.

- $\quad$ Photovoltaic is associated with local utility.

- $\quad$ Photovoltaic including generator backup power.

- It depends on utility scale renewable energy production.

- Hybrid renewable energy schemes.

\section{MATHEMATICAL MODELING OF SOLAR PHOTOVOLTAIC SYSTEMS}

\section{A. Designing of Solar Photovoltaic system}

Designing of solar photovoltaic scheme can be performed in four possible stages:

- $\quad$ Estimating the Load

- $\quad$ Estimating the PV panel quantities

- $\quad$ Estimating the battery bank

- $\quad$ Estimating the total system cost.

Consider Example: Load requirements of home appliances: 4 CFL light (15 Watts for each), 2 ceiling Fans (75 Watts for each), and 2 Laptop (100 Watts for each) 7 hours per day.

(a) Total requirement of energy that connected to photovoltaic panel system.

$=$ Number of quantity $x$ ratings of the appliances (watts)

$=4 \times 15+2 \times 75+2 \times 100=410$ watts.

(b) Rating of total watt-hours of the photovoltaic panel structure

$=$ the amount of energy required for the system $\mathrm{x}$ operating hours a day

$=410 \times 7=2,870$ Watt-hours per day

(c) Actual output power of a photovoltaic panel system per day= rating of maximum power $\mathrm{x}$ rating of system

$$
\text { Operating factor } \quad=40 \times 0.75=30 \text { Watts }
$$

Power utilized because the system's combined efficiency is low = Actual power output of a PV panel system per day $\mathrm{x}$ combined efficiency.

$=30 \times 0.81=24.3$ watts

One forty of energy created in WP panel per day=Actual power output of a PV panel system per day $\mathrm{x}$ six hours/day

$=24.3 \times 7=145.8$ watts-hour per day.

(d) Number of photovoltaic panels are required to meet periodically the load estimated $:=($ total watt-hour rating per day)/ (total power created by a solar PV system per day) $=2870 / 145.8=20$ panels.

(e) Size of the Inverter is calculated by the amount of load connected to solar photovoltaic structure.

Suppose the amount of load connected to the solar photovoltaic structure is 186 Watts.
Inverter ratings available for $\mathrm{PV}$ panel systems are 100 VA, $200 \mathrm{VA}$, and $500 \mathrm{VA}$

Thus, $200 \mathrm{VA}$ is preferred for Inverter.

(f)Array cost $=$ Number of Solar photovoltaic modules that satisfy the daily load estimated x Cost/Module of the Solar PV panels

$=20 \times 8000$ (for 40 watt-power panel at Rs.200/wattpower) $=$ Rs. $1,60,000$

(g) Battery cost $=$ Number of Battery required for the panels x Cost/Module of the solar PV panels.

$=1 \times 7500=$ Rs. 7500

(h) Inverter cost=Number of Inverters x Cost/Inverter of the solar PV panels

$=1 \times 5000=$ Rs. 5000

Total System cost $=$ Array Cost + Battery Cost + Inverter Cost

$=1,60,000+7500+5000=$ Rs. $1,72,500$

Derivation of PV cell characteristics is given by

$\mathrm{I}_{\mathrm{p}}=\mathrm{I}_{\mathrm{d}}+\mathrm{IR}_{\mathrm{sh}}+\mathrm{I}$

Where

$\left.\mathrm{I}=\mathrm{I}_{\mathrm{p}}-\mathrm{I}_{\mathrm{d}}-\left(\left(\mathrm{V}+\mathrm{IR}_{\mathrm{s}}\right) / \mathrm{R}_{\mathrm{sh}}\right)\right)$

$\mathrm{I}_{\mathrm{d}}=\mathrm{I}_{0}\left(\mathrm{e}^{\mathrm{v}+\mathrm{iRs} / \mathrm{nV}}{ }_{\mathrm{T}}-1\right)$ from PN junction theory.

Where

$I_{p}$ represents photo current (depends on solar intensity radiation), current generated by photons

$\mathrm{I}_{0}$ represents saturation current of the diode.

$\mathrm{V}$ denotes voltage output.

$\mathrm{Q}$ represents electron charge.

I denotes output current

$\mathrm{R}_{\mathrm{s}}$ denotes series resistance

$\mathrm{R}_{\mathrm{sh}}$ denotes shunt resistance

$\mathrm{n}$ represents ideality factor.

Where $\mathrm{V}_{\mathrm{T}}=\mathrm{KT} / \mathrm{q}=\mathrm{T} / 11600$

If $\mathrm{n}=2, \mathrm{I}_{0}=\mathrm{KT}^{\mathrm{m}} \mathrm{e}^{-\mathrm{VG} 0 / \mathrm{nVT}}$

Where $\mathrm{I}_{0}=$ reverse saturation current. Depends on temperature.

Where $\mathrm{I}_{0}=\mathrm{KT}^{\mathrm{m}} \mathrm{e}_{0}^{-\mathrm{vG} / \mathrm{nV}}$

$\mathrm{K}=$ Boltzmann constant depends on dimension of $\mathrm{PN}$ junction and material property.

$\mathrm{VG}_{0}=$ forbidden bandgap energy $\mathrm{EG}_{0}$ in ev.

If $\mathrm{m}=1.5$ for $\mathrm{Si}$

$\mathrm{VG}_{0}=1.16$ to $1.21 \mathrm{v}$ for $\mathrm{Si}$

$\mathrm{I}=\mathrm{I}_{\mathrm{p}}-\mathrm{I}_{0}\left(\mathrm{e}^{\mathrm{V}+\mathrm{IRs} / \mathrm{nVT}}-1\right)-\left(\mathrm{V}+\mathrm{IR}_{\mathrm{s}} / \mathrm{R}_{\mathrm{sh}}\right)$

Parameters of PV cell are $I_{\mathrm{sc}}$ and $\mathrm{V}_{\mathrm{oc}}$

To calculate $\mathrm{I}_{\mathrm{sc}}\left(\mathrm{R}_{\mathrm{s}}<<\mathrm{R}_{\mathrm{sh}}\right)$

$\mathrm{I}_{\mathrm{sc}}=$ Photo current is proportional to solar power.

To calculate $\mathrm{V}_{\mathrm{oc}}\left(\mathrm{R}_{\mathrm{sh}}>>\mathrm{V}_{\mathrm{oc}}\right)$

Then $\mathrm{Voc}=\mathrm{nVT} \ln (\mathrm{ip}+\mathrm{I} / \mathrm{I} 0)$

\section{SIMULATION RESULTS OF SOLAR PHOTOVOLTAIC SYSTEMS\& RESULTS}

Operation of Photovoltaic Cell implies when light falls on this glass surface, the top surface of PN Junction which is $\mathrm{N}$-type and valence electrons gets excited and move into the conduction band. The top metallization moves into the negative terminal and then flows out into the external circuit and into the anode terminal comes back to the P-Substrate

Published By:

Blue Eyes Intelligence Engineering

\& Sciences Publication 
through bottom metallization [11]. Always current flows from Anode to Cathode. Diode act as a Sink circuit, in which power flow into the device and act as a sink that is in Fourth quadrant of IV characteristics of Diode. By adding current source in the circuit, current direction changes. More solar radiation gives higher photo current, large current and large power flow. Photo current is directly proportional to solar intensity. Constant current line implies high value of shunt resistance across constant current source, so include shunt resistance. Constant voltage line implies series impedance at the terminal, so include series resistance. Figure 2 represents PV solar cell's equivalent circuit.

Issue in IV characteristics have detrimental effect on the overall module or individual cell in series. Issue in nonidentical cells in series are result of IV characteristics, how power versus current curve, power sourcing and sink issues [14]. Protection of series modules is done by placing bypass diode that will bypass the panel and protected. Figure 4 represents MATLAB Simulink model for IV characteristics of solar photovoltaic cell. Figure 5 depicts the design to generate reverse saturation current by MATLAB Simulink. Figure 6.depicts the design to generate photo current by MATLAB Simulink. Figure 7 depicts the design to generate saturation current by MATLAB Simulink. Figure 8 depicts the design to generate shunt resistance current by MATLAB Simulink model. Figure 9.depicts the design to generate current output of PV array by MATLAB Simulink model. Figure 10.represents design of solar photovoltaic cell using parameters by MATLAB Simulink.

Solar photovoltaic cell is operated at the maximum power point, using MPPT algorithm to produce maximum output. It encompasses an Ideal current source that are connected in parallel along with an ideal diode [18] .The output remains constant with constant incident of light and constant temperature. Solar photovoltaic cells have two important parameters such as open-circuit voltage $\left(\mathrm{V}_{\mathrm{oc}}\right)$ as well as short circuit current $\left(\mathrm{I}_{\mathrm{sc}}\right)$.The short circuit current $\left(\mathrm{I}_{\mathrm{sc}}\right)$ is generated when the photovoltaic module are short circuited. In the absence of resistance in the circuit, current reaches its maximum capacity. The open-circuit voltage $\left(\mathrm{V}_{\mathrm{oc}}\right)$ is generated if there is infinite resistance and no current flow in the circuit that will produce maximum voltage. Figure 3 illustrates the five parameters of a two-diode equivalent circuit model is utilized widely in a solar photovoltaic cell. The shunt resistance is rejected as it has large value. Therefore, the five parameters circuit model can be simplified into four parameters circuit model. In five parameter circuit model, the saturation current in second diode and parallel impedance is assumed to be zero. Figure 11 Shows voltage versus power characteristics of PV system. Figure 12 represents voltage versus current characteristics of photovoltaic system.

In Figure 13.Current increases linearly with respect to irradiance and voltage increases logarithmically. At $25^{\circ}$ Celsius, current increases by $1 \%$ per cell and voltage decreases by $2 \mathrm{mv} /{ }^{\circ}$ Celsius per cell. Drop in voltage will increase when number of solar cells are in series connection. In Figure 12 depicts constant at $25^{\circ}$ Celsius and irradiance of $1000 \mathrm{~W} / \mathrm{m}^{2}$ will generate the PV characteristic curve. The current produced by the incident of light depends on irradiance and current. By connecting number of solar cells in series connection the output voltage of solar PV cell is improved. Figure 13. Shows the solar PV cell of voltage versus power characteristics. Figure 14.represents the energy obtained from PV under various irradiance such as $400 \mathrm{~W} / \mathrm{m}^{2}, 600 \mathrm{~W} / \mathrm{m}^{2}, 800 \mathrm{~W} / \mathrm{m}^{2}, 1000 \mathrm{~W} / \mathrm{m}^{2}$.

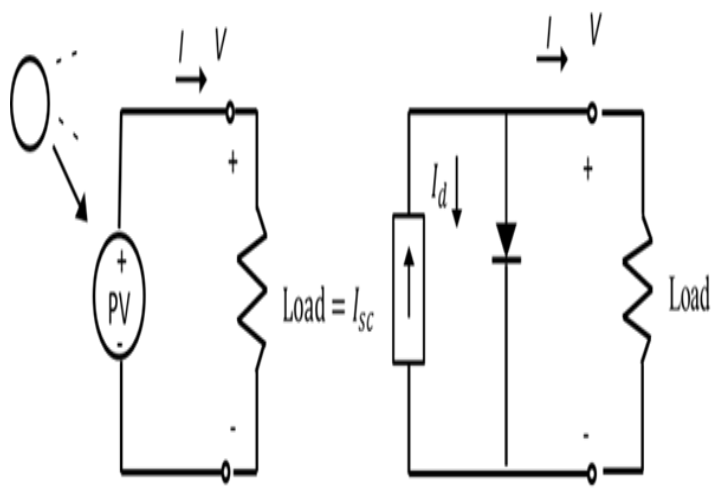

Figure 2 Equivalent circuit for Solar PV structure

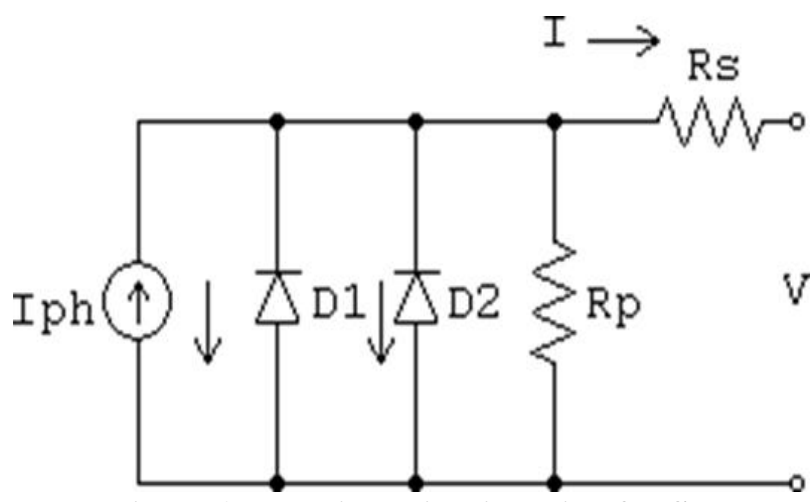

Figure 3 Two diode circuit design for Solar PV structure

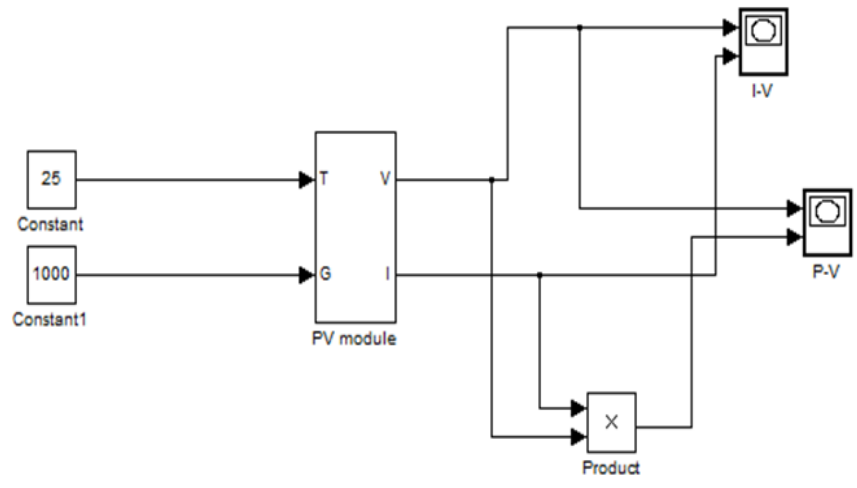

Figure 4 Simulink model for IV characteristics of photovoltaic system 


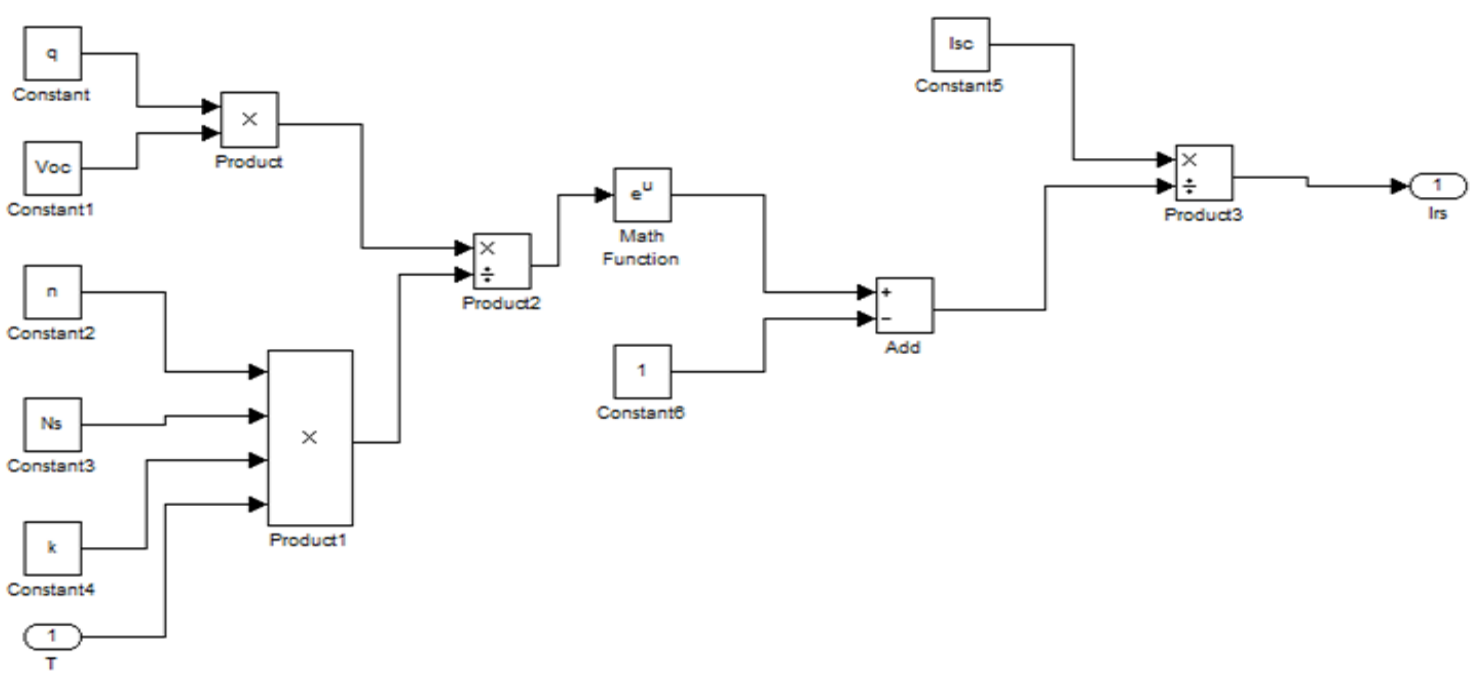

Figure 5 Design of Reverse saturation current using Simulink

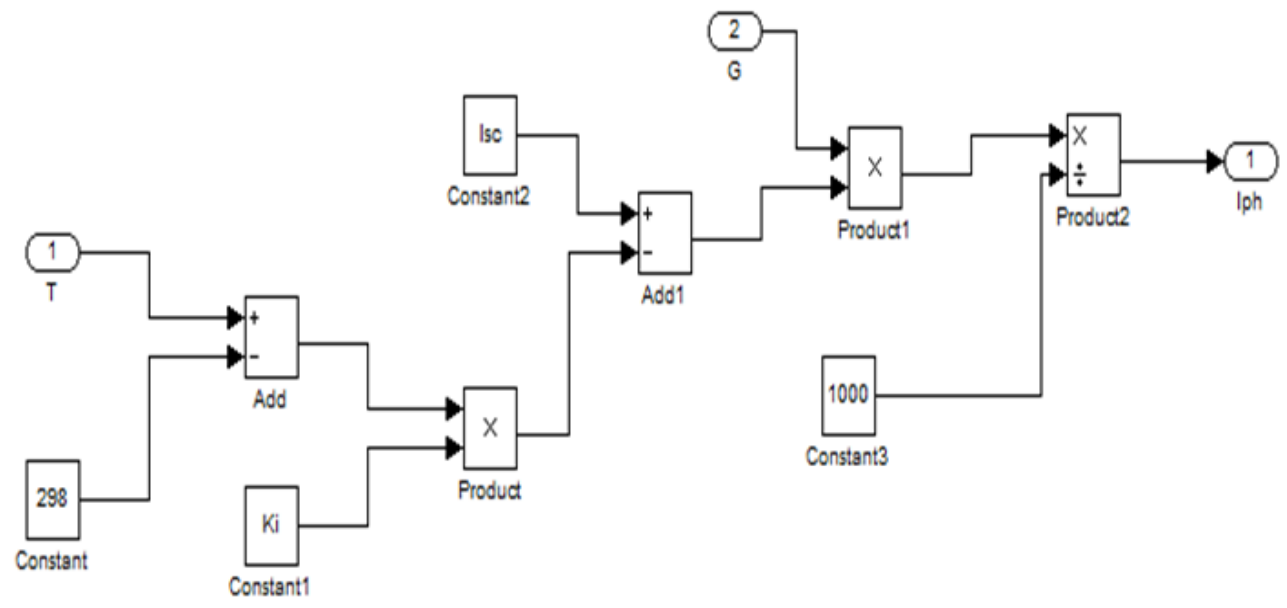

Figure 6 Design of Photo current using Simulink

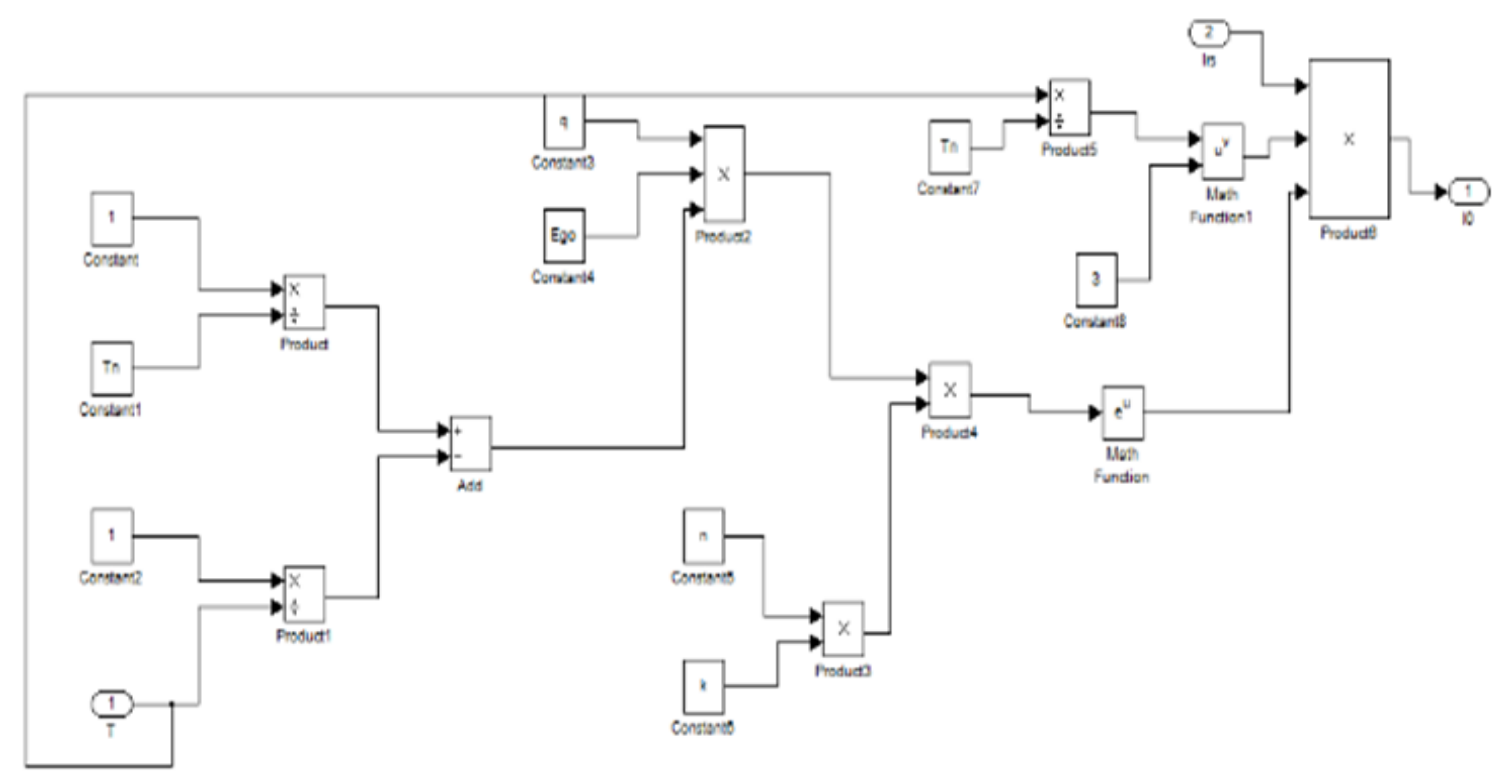

Figure 7 Design of Saturation current using Simulink

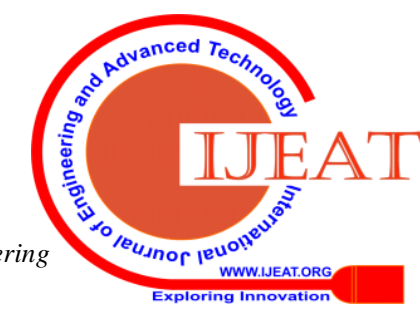




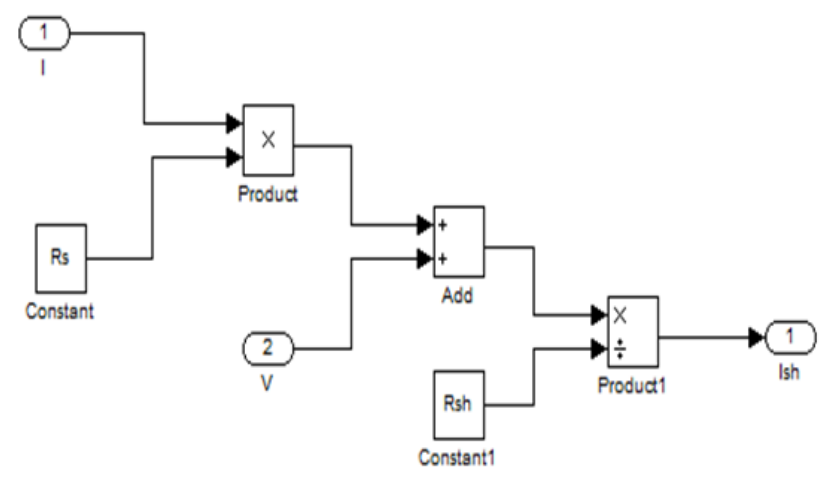

Figure 8 Design of Shunt resistor current using Simulink

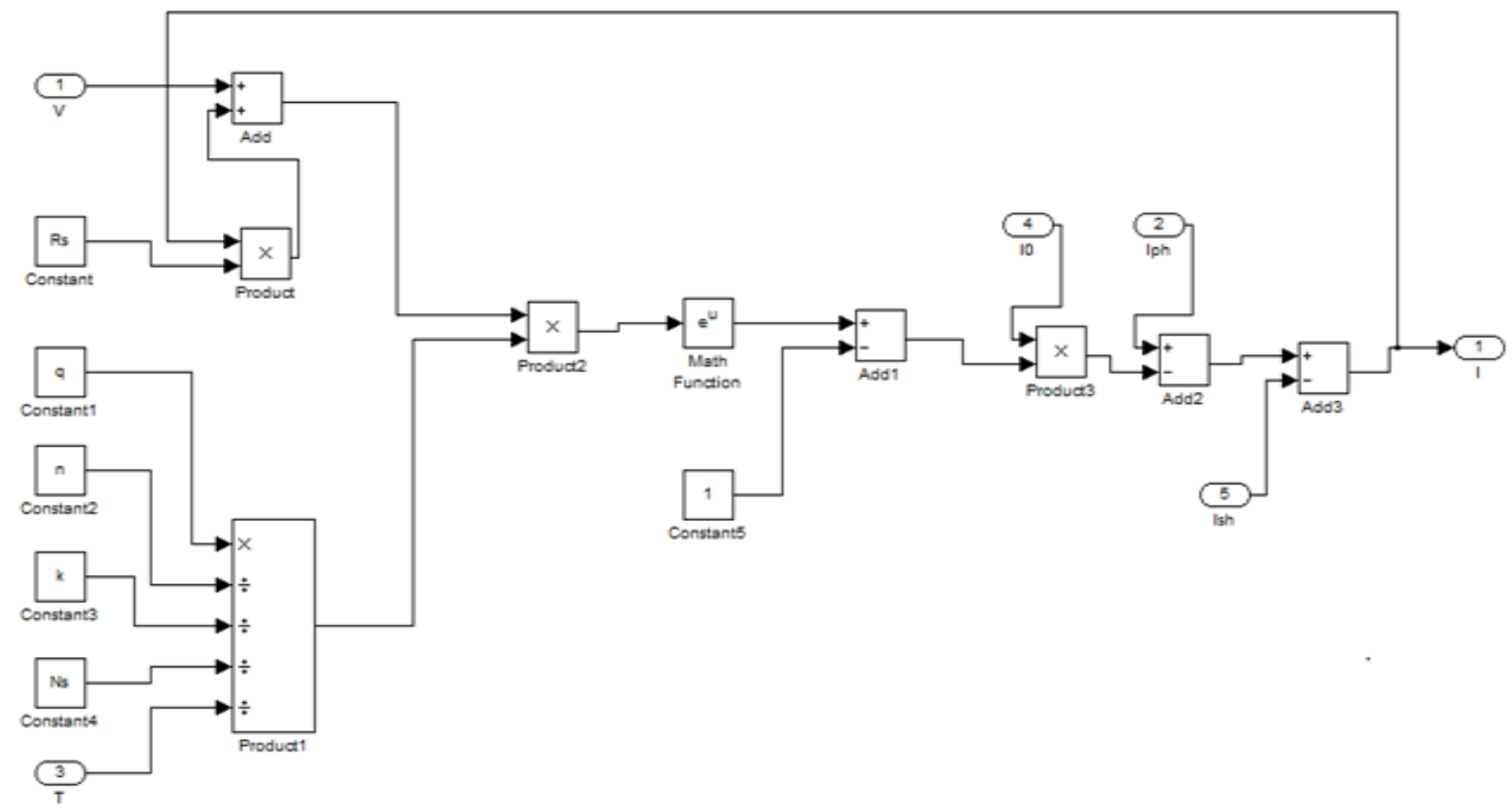

Figure 9 Design of PV array output current using Simulink

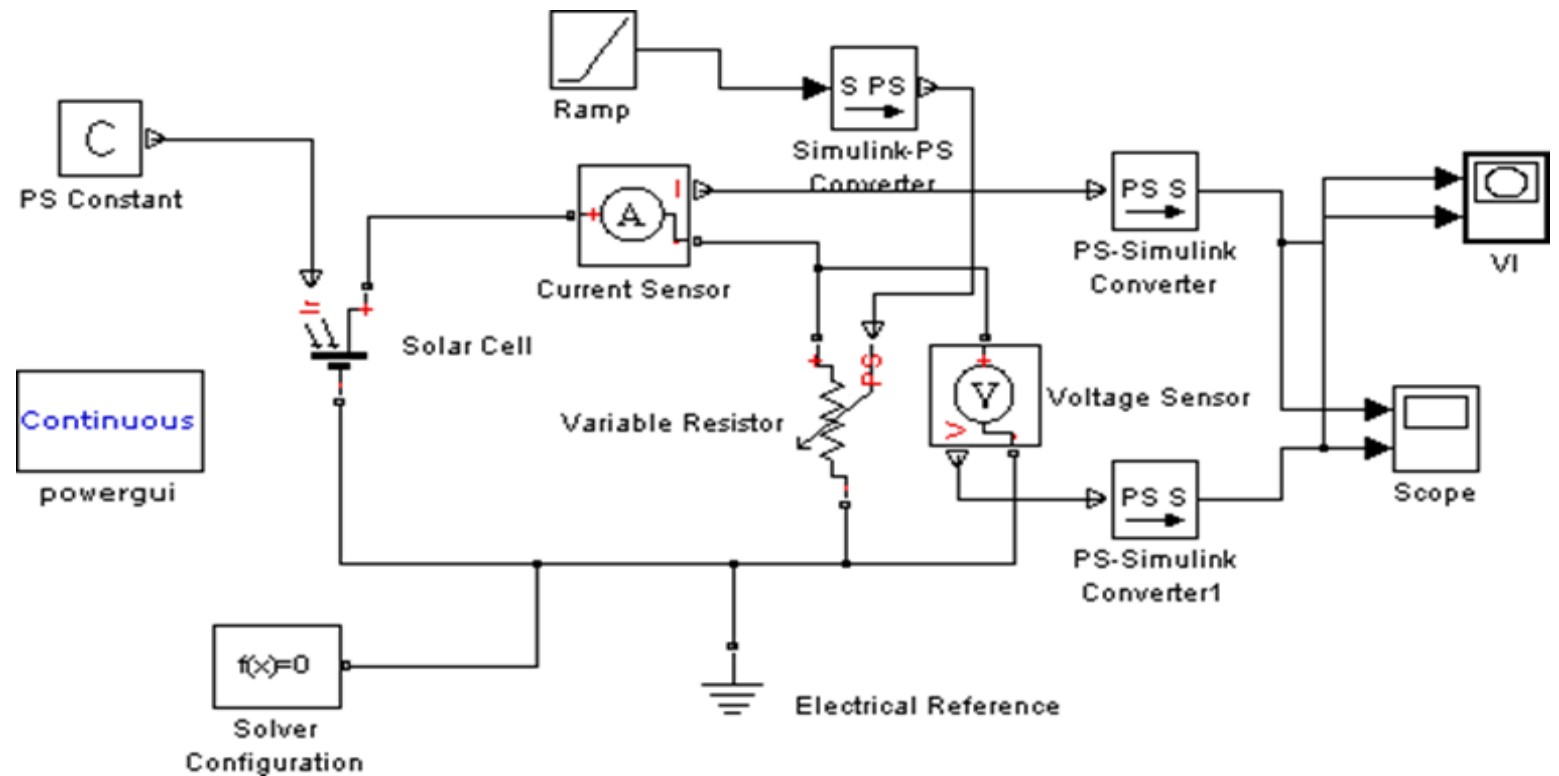

Figure 10 Simulink model for solar PV cell

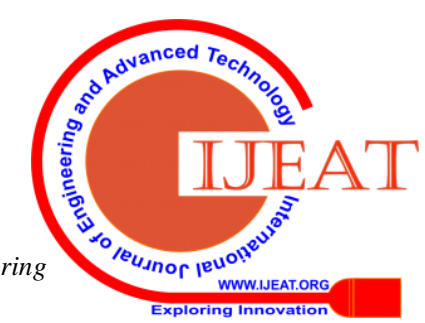




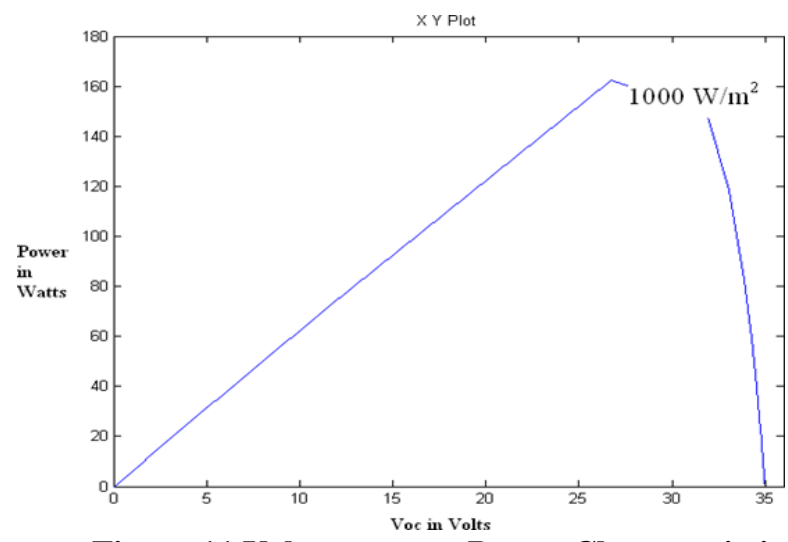

Figure 11 Voltage versus Power Characteristics of Photovoltaic system

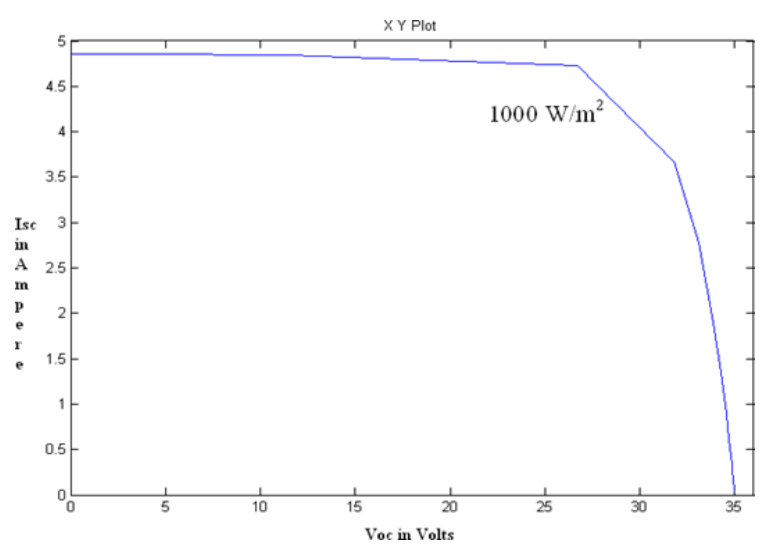

Figure 12 Voltage versus Current Characteristics of Photovoltaic system

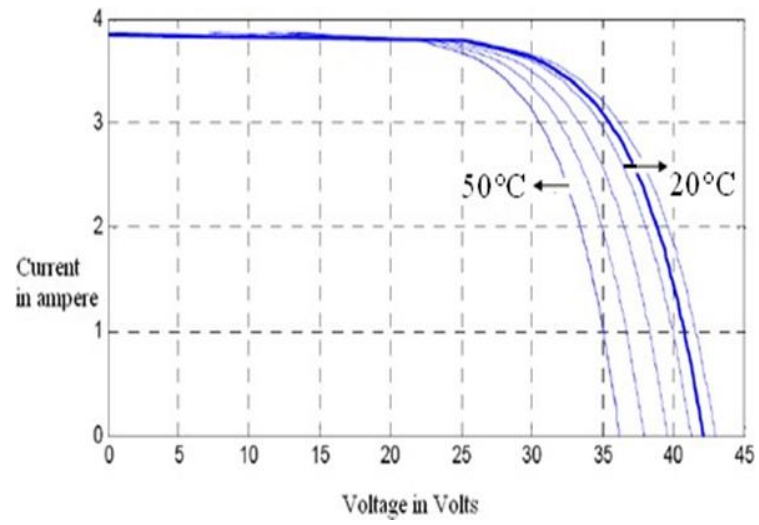

Figure 13 Voltage versus Current characteristics of photovoltaic system at various temperature

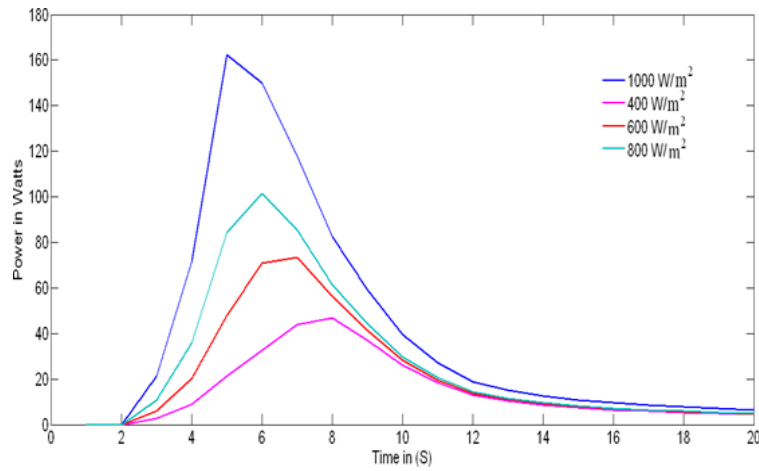

Figure 14 Solar photovoltaic cell power curve at different irradiance

\section{CONCLUSION}

In this article modeling of solar photovoltaic system and performance of different parameters are performed by MATLAB Simulink and results are presented. This article concluded that the power electronics used in sustainable energy are subjected to expand in Research\& Development, particularly on more powerful control ideas ,converters as well as distributed generation has a demand along with demanding role in the future for efficient adequate of energy generating and power distributing. In future, Hybrid energy systems are combining two or more sustainable energy sources together which leads to improve efficiency of the system and maintaining the energy supply.

\section{REFERENCES}

1. Forster R. Let there be Light..but what comes next? Changing energy needs and the ability of decentralized solar energy to provide sustainable solutions to urban slum communities in Bangalore, India. Edinburgh research archive;2014. Available:http://www.era.lib.ed.ac.uk/handle/1842/10397 [2.06.2015].

2. Solar Energy in India-Pros, Cons and the Future.(http://www.mapsofindia.com/myindia/india/scope-of-solar-energy-in-india-pros-cons-and -the future)[accessed 07.01.15]

3. Dna. Home.Diligent Media Corporation Limited;2014.Available :www.dnaindia.com dated [15.04.14].

4. Status of PV manufacturing in India.(http://intersolar.in/en/for-press/news/industrynews/status -of-PV-manufacturing-inInida.html)[accessed 07.01.15].

5. Solar water heating systems: A Review of Global Experiences.(http://www.aeinetwork.org/reep/doc/DIRE C_Background.pdf)[accessed 22.06.15]

6. Solar Water Heating Telescope Market Readiness Assessment.(http://www.in.mdp.org/content/dam/india/d oes/EdE/solar-water-heating-techscope-marketreadiness-assessment.pdf) [accessed 22.06.15].

7. Solar Energy Potential in Industries(http://mnre.gov.in/filemanager/UserFiles/solar_energy_potential_in_industries. pdf) [accessed 24.06.15].

8. PhotovoltaicPowersystemprogramme.(http://www.ieapvps.org/fileadmin/dam/public/report/statistics/PVPSreport_A_smapshot_of_Global_PV_19922013 final_3.pdf) [accessed 25.06.15].

9. Kapoor K, Pandey KK,Jain AK, Nandan A. Evolution of solar energy in India: A review.Renewable and sustainable Energy Reviews 2014;40:475-487.

10. Sisodia, GS, Soares I, Banerji S, Poel DVD.The status of Energy Price Modelling and its Relevance to Marketing in Emerging Economies.Energy Procedia 2015;79:500505 .

11. Brouwer AS, van den Broek M,Seebregts A, Faaij A.Impacts of large-scale intermittent renewable energy sources on electricity systems, and how these can be modeled. Renewable Sustainable Energy Reviews 2014;33:443-466.

12. Design and simulation of Stand Alone photovoltaic systems., WSEAS Transaction on power systems,Salima Kebaili, Achour Betka, issue 4, volume 6, October 2011.

13. Design of Stand Alone Solar Photovoltaic system for 
Residential Buildings, Ibrahim, U.H.,D.A.Aremu,Unwaha, J.I., IJSTR volume 2, Issue 12, December 2013.

14. J.T.Bialasiewicz, "Renewable energy systems with photovoltaic power generators: operation and modeling", IEEE Trans. Ind. Electron., vol. 55,no.7,pp.27522758.Jul.2008.

15. B.Yang, W.Li, Y.Zhao, and X.He, "Design and analysis of a grid connected photovoltaic power system", IEEE Trans.Power Electron, Vol.25, no.4,pp.992-1000, April.2010.

16. R.J.Wai, W.H.Wang and C.Y.Lin, "High-performance stand-alone photovoltaic generation system", IEEE Trans. Ind. Electron, vol.55, no.1, pp.240-250, Jan 2008.

17. R.J.Wai and W.H.Wang, "Grid-connected photovoltaic generation system", IEEE Trans. Circuits Syst. I,Reg. Papers,vol 55, no.3, pp.953-964,April. 2008

18. F.Blaabjerg, F.Lov, T.Kerekes, and R.Teodorescu,'Trends in power electronics and control of renewable energy systems", $14^{\text {th }}$ Int. power electronics and motion control conf.(EPE/PEMC)1, K-1to K19(2010)

19. Akshay B.Zade, Asha Gaikwad, Ku.Prachi M.Jeevane, Ganesh Lohote.: Hybrid Solar and wind power generation with Grid Interconnection System for Improving Power Quality .International conference on Power Electronics, Intelligent Control and Energy Systems IEEE, 2016.

20. Mubashar YaqoobZargar, Mairaj-ud-Din Mufti, Shameem Ahmed Lone.: Modelling and Control of Wind Solar Hybrid System using Energy Storage system.In: International Conference on Computing, Communication and Automation, IEEE, 2016.

21. Muhammad H.Rashid,"Power Electronics Handbook",Ph.D., Fellow IEE, Fellow IEEE,Academic press,Copyright 2001

22. Fragkiadakis I., "Photovoltaic systems",Professor of T.E.I of Crete, Zito Press, Copyright 2004.

23. Papadopoulos Michalis, "Energy production from renewable energy applications", Professor of National University of Athens, Copyright 1997 by National University of Athens.

24. Altenburg T,Engelmeier T.Boosting solar investment with limited subsidies:Rent management and policy learning in India.Energy policy 2013;59:866-874.

25. Harish SM, Iychettira KK, Raghavan SV,Kandlikar M.Adoption of solar home lighting systems in India:what might we learn from Karnataka? Energy policy 2013;62:697-706.

26. "Renewable Energy Sources and Emerging Technologies", Eastern Economy Edition, D.P.Kothari, K.C.Singal and Rakesh Ranjan.

\section{AUTHORS PROFILE}

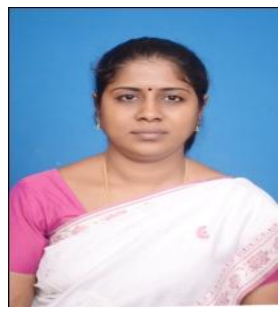

Dr.A.Sumathi received Ph.D. degree in Information and communication engineering from Anna University, Chennai in 2009. She received M.E degree in Applied electronics from Anna university, Chennai in 2004 and B.E degree in Electronics and communication Engineering from Bharathiar university, Tamilnadu in 1994.She is now working as Professor and Head of Electronics and Communication Engineering Department, Adhiyamaan college of Engineering, Hosur. She is a recipient of Bharat Jyothi Award instituted by India International Friendship Societyas recognition to her research work and academic excellence. She has published about 70 research papers in referred Journals, 25 in conference proceedings She has membership in various professional societies such as Member of IEEE (USA), Fellow Member of Institution of Engineers (India), Life Member of Indian Society of Technical Education and Member of VLSI Society of India.

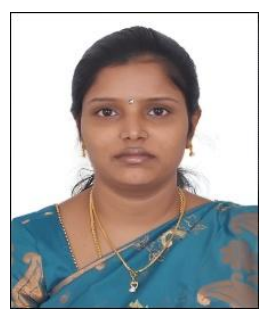

Bharathy Priya D., received the B.E degree in Electrical and Electronics Engineering from Madurai Kamaraj University, Tamilnadu in the year 2003. She received the M.E degree in power electronics and Drives from Anna University, Chennai in the year 2006. She is currently pursuing the Ph.D. degree in Electrical Engineering, Adhiyamaan College of Engineering, Hosur, Anna University. Her research interests includes designing and controlling of power electronic converters, renewable energy source applications. 